\title{
HUBUNGAN PENGETAHUAN KANKER LEHER RAHIM DENGAN MOTIVASI WANITA PASANGAN USIA SUBUR MELAKUKAN PEMERIKSAAN IVA (Di RT 02 RW 02 Desa Surat Kecamatan Mojo Kabupaten Kediri)
}

\author{
Lia Agustin ${ }^{1}$, Nour Fauziyah ${ }^{2}$ \\ ${ }^{1,2}$ Akademi Kebidanan Dharma Husada Kediri Jawa Timur
}

\begin{abstract}
Abstrak
Kanker serviks merupakan keganasan yang terjadi pada leher rahim yang merupakan bagian terendah dari rahim yang menonjol ke puncak liang senggama. Kanker leher rahim banyak ditemukan di negara berkembang seperti Indonesia. Salah satu yang mempengaruhi tingginya angka kejadian kanker leher rahim adalah kurangnya motivasi masyarakat untuk melakukan skrining.Tujuan penelitian ini adalah mengetahui hubungan antara pengetahuan kanker leher rahim dengan motivasi wanita pasangan usia subur melakukan pemeriksaan IVA.

Desain penelitian ini adalah penelitian korelasional dengan pendekatan cross sectional. Populasi yang diteliti meliputi seluruh wanita pasangan usia subur usia 15-49 tahun di RT.02 RW.02 Ds.Surat Kec.Mojo Kab.Kediri berjumlah 36 responden. Teknik sampling yang digunakan adalah total sampling, seluruh populasi dijadikaan responden. Variabel dependen pengetahuan wanita pasangan usia subur tentang kanker leher rahim dan variabel independen motivasi wanita pasangan usia subur melakukan pemeriksaan IVA. Instrumen penelitian ini adalah kuesioner. Pengolahan data dengan editing, coding, scoring, tabulating dan kemudian dilakukan analisa data menggunakan uji spearman rank.

Hasil penelitian ini menunjukkan bahwa mayoritas memiliki pengetahuan yang kurang yaitu 26 responden $(72,2 \%)$ dan motivasi rendah yaitu 20 responden (55,5\%). Hasil uji Spearman Rank didapatkan $\rho$-value sebesar $0.017<\alpha(0.05)$ dan $\mathrm{r}=0,394$, artinya ada hubungan antara pengetahuan wanita pasangan usia subur tentang kanker leher rahim dengan motivasi wanita pasangan usia subur melakukan pemeriksaan IVA di RT.02 RW.02 Ds.Surat Kec.Mojo Kab.Kediri.

Dengan adanya hubungan pengetahuan kanker leher Rahim dengan motivasi wanita pasangan usia subur melakukan pemeriksaan IVA di RT.02 RW.02 Ds.Surat kec.Mojo Kab.Kediri. peneliti menyarankan hendaknya tenaga kesehatan meningkatkan partisipasi dalam memberikan penyuluhan kepada masyarakat tentang kanker leher rahim dan cara pencegahanya.
\end{abstract}

Kata kunci : Pengetahuan, Kanker Leher Rahim, Motivasi, Wanita Pasangan Usia Subur, IVA

Korespondensi: Ds. Tales RT 002/RW 003 Kediri Jawa Timur HP: 081335413169 ,email: liaagustin77.la@gmail.com 
Lia Agustin: Hubungan Pengetahuan Kanker Leher Rahim Dengan Motivasi Wanita Pasangan Usia Subur Melakukan Pemeriksaan IVA di RT 02 RW 02 Desa Surat Kecamatan Mojo Kabupaten Kediri

\section{Pendahuluan}

Kanker leher rahim masih banyak ditemukan di negara yang sedang berkembang seperti Indonesia (Samadi,P,2010:1). Dari data Badan Kesehatan Dunia diketahui terdapat 493.243 jiwa per tahun penderita kanker leher rahim baru di dunia dengan angka kematian karena kanker ini sebanyak 273.505 jiwa per tahun (Emilia,O,2010:11). Salah satu faktor yang mempengaruhi masih tingginya angka kejadian kanker leher rahim adalah kurangnya motivasi masyarakat untuk melakukan skrining atau deteksi dini kanker leher rahim. Disisi lain kesadaran dan pengetahuan masyarakat tentang kanker termasuk faktor-faktor risiko dan upaya pencegahan masih kurang (Septadina,S,2007). Berbeda dengan di negara maju, cakupan progam skrining di Indonesia baru sekitar 5\%. Padahal, di negara maju progam skrining sudah dilaksanakan sejak beberapa dekade.(Samadi,P,2010:1).

Berdasarkan data WHO penyakit kanker merupakan penyebab kematian terbanyak di dunia, dimana kanker sebagai penyebab kematian nomor 2 di dunia sebesar $13 \%$ setelah penyakit kardiovaskular. Setiap tahun, 12 juta orang di dunia menderita kanker dan 7,6 juta di antaranya meninggal dunia. Diperkirakan pada 2030 kejadian tersebut dapat mencapai hingga 26 juta orang dan 17 juta di antaranya meninggal akibat kanker, terlebih untuk negara miskin dan berkembang kejadiannya akan lebih cepat. (Kemenkes RI, 2015). Di Indonesia, kasus kanker leher rahim menempati urutan pertama dengan jumlah kasus 14.368 orang. Dari jumlah itu, 7.297 di antaranya meninggal dunia (Kustiyati,S,2011).

Di Kabupaten Kediri kasus IVA positif ada $0,04 \%$ dari jumlah keseluruhan wanita PUS dan tahun $2015 \quad 3,20 \% \quad$ (Dinas Kesehatan

Kab.Kediri,2017).

Bedasarkan hasil pengumpulan data di Puskesmas Mojo kejadian kanker leher rahim pada tahun 2012-2014 6 kasus, tahun 2015Februari 20175 kasus. Sedangkan kanker leher rahim Di desa surat tahun 2012-2014 1 kasus, 2015-Februari 20172 kasus.

Rumusan masalah sebagai berikut : Apakah ada hubungan antara pengetahuan kanker leher Rahim dengan motivasi melakukan pemeriksaan IVA pada wanita pasangan usia subur di RT.02 RW.02 Ds. Surat Kec. Mojo Kab. Kediri Tahun $2017 ?$

\section{Metode}

Pada penelitian ini peneliti menggunakan rancangan penelitian korelasional dengan menggunakan pendekatan cross sectional. Penelitian dilaksanakan di RT 02 RW 02 Ds. Surat Kecamatan Mojo. Populasi dalam penelitian ini adalah semua wanita pasangan usia subur usia 15-49 tahun di RT 02 RW 02 Desa Surat Kecamatan Mojo Kabupaten Kediri yang berjumlah 36 orang. Teknik sampling menggunakan total sampling dengan cara mengambil semua populasi menjadi sampel. Variabel independen penelitian ini adalah pengetahuan wanita pasangan usia subur tentang kanker leher rahim. Variabel dependen penelitian ini adalah motivasi wanita pasangan usia subur melakukan pemeriksaan IVA. Instrumen yang digunakan dalam penelitian ini adalah kuesioner, yang telah di uji validitas dan reliabilitas, dan di Analisa dengan Spearman Rank (Rho)

\section{HASIL}

Hasil penelitian yang dilakukan terhadap 36 responden di RT.02 RW.02 Ds. Surat Kec. Mojo Kab. Kediri diperoleh data sebagai berikut : 
Tabel 1.Distribusi Frekuensi Wanita Pasangan Usia Subur Berdasarkan Umur Di RT.02 RW.02 Ds. Surat Kec. Mojo Kab. Kediri

\begin{tabular}{cccc} 
No & Usia & Frekuensi & Prosentase (\%) \\
\hline 1 & $<20$ tahun & - & - \\
\hline 2 & $20-35$ tahun & 19 & 52,8 \\
\hline 3 & $>35$ tahun & 17 & 47,2 \\
\hline & Total & 36 & 100
\end{tabular}

Berdasarkan tabel.1 diketahui bahwa mayoritas dari responden, yaitu 19 responden $(52,8 \%)$ berusia $20-35$ tahun dan minoritas dari responden, yaitu 17 responden $(47,2 \%)$ berusia $>$ 35 tahun.

Tabel 2. Distribusi Frekuensi Wanita Pasangan Usia Subur Berdasarkan Pekerjaan Di RT.02 RW.02 Ds. Surat Kec. Mojo Kab. Kediri

\begin{tabular}{cccc} 
No. & Informasi & Frekuensi & Prosentase (\%) \\
\hline 1 & Swasta & 2 & 5,5 \\
\hline 2 & Wiraswasta & 2 & 5,5 \\
\hline 3 & TNI/POLRI & - & - \\
\hline 4 & PNS & - & - \\
\hline 5 & Ibu Rumah Tangga & 31 & 86,2 \\
\hline 6 & Lain-lain & 1 & 2,8 \\
\hline & Total & 36 & 100
\end{tabular}

Berdasarkan tabel.2 diketahui bahwa mayoritas dari responden, yaitu 31 responden $(86,2 \%)$ tidak bekerja atau sebagai ibu rumah tangga dan minoritas dari responden, yaitu 1 responden $(2,8 \%)$ bekerja lain-lain.

Tabel 3. Karekteristik Wanita Pasangan Usia Subur Berdasarkan Pendidikan Di RT.02 RW.02 Ds. Surat Kec. Mojo Kab. Kediri

\begin{tabular}{cccc} 
No. & Pendidikan & Frekuensi & Prosentase (\%) \\
\hline 1 & Tidak sekolah & - & - \\
\hline 2 & SD/MI-SMP/MTS & 30 & 83,3 \\
\hline 3 & SMA/MA & 6 & 16,7 \\
\hline 4 & D3-PT & - & - \\
\hline & Total & 36 & 100
\end{tabular}

Berdasarkan tabel.3 diketahui bahwa mayoritas dari responden, yaitu 30 responden $(83,3 \%)$ berpendidikan
SD/MI-SMP/MTS dan minoritas dari responden, yaitu 6 responden $(16,7 \%)$ berpendidikan
SMA/MA.

a. Karakteristik Responden Berdasarkan Informasi 
Lia Agustin: Hubungan Pengetahuan Kanker Leher Rahim Dengan Motivasi Wanita Pasangan Usia Subur Melakukan Pemeriksaan IVA di RT 02 RW 02 Desa Surat Kecamatan Mojo Kabupaten Kediri

Tabel.4 Karekteristik Wanita Pasangan Usia Subur Berdasarkan Informasi Di RT.02 RW.02 Ds. Surat Kec. Mojo Kab. Kediri

\begin{tabular}{cccc} 
No. & Informasi & Frekuensi & Prosentase (\%) \\
\hline 1 & Tidak pernah & 6 & 16,7 \\
\hline 2 & Pernah & 30 & 83,3 \\
\hline & Total & 36 & 100
\end{tabular}

Berdasarkan tabel.4 diketahui bahwa mayoritas dari responden, yaitu 30 responden $(83,3 \%)$ pernah mendapat informasi tentang kanker leher rahim dan minoritas dari responden, yaitu 6 responden $(16,7 \%)$ tidak pernah mendapatkan informasi tentang kanker leher rahim.

b. Karakteristik Responden Berdasarkan Sumber informasi

Tabel 5. Karakteristik Wanita Pasangan Usia Subur Berdasarkan Sumber Informasi Di RT.02 RW.02 Ds. Surat Kec. Mojo Kab. Kediri

\begin{tabular}{cccc} 
No. & Sumber Informasi & Frekuensi & Prosentase (\%) \\
\hline 1 & Petugas Kesehatan & 10 & 27,8 \\
\hline 2 & Media massa & 13 & 36,1 \\
\hline 3 & Media elektronik & 4 & 11,1 \\
\hline 4 & Orang lain & 3 & 8,3 \\
\hline 5 & Tidak mendapat informasi & 6 & 16,7 \\
\hline & Total & 36 & 100
\end{tabular}

Berdasarkan tabel.5 diketahui bahwa mayoritas dari responden, yaitu 13 responden $(8,3 \%)$ mendapat informasi responden $\quad(36,1 \%) \quad$ mendapatkan informasi dari media massa dan minoritas dari responden, yaitu 3

Tabel 6. Hubungan Pengetahuan Kanker Leher Rahim Dengan Motivasi Wanita Pasangan Usia Subur Melakukan Pemeriksaan IVA Di RT.02 Rw.02 Ds. Surat Kec. Mojo Kab. Kediri

\begin{tabular}{|c|c|c|c|c|c|c|c|c|}
\hline \multirow{3}{*}{ Pengetahuan } & \multicolumn{6}{|c|}{ Motivasi } & \multirow{2}{*}{\multicolumn{2}{|c|}{ Jumlah }} \\
\hline & \multicolumn{2}{|c|}{ Tinggi } & \multicolumn{2}{|c|}{ Cukup } & \multicolumn{2}{|c|}{ Rendah } & & \\
\hline & $\mathbf{N}$ & $\%$ & $\mathbf{N}$ & $\%$ & $\mathbf{N}$ & $\%$ & $\mathbf{N}$ & $\%$ \\
\hline Baik & 1 & 2,8 & 1 & 2,8 & 1 & 2,8 & 3 & 8,33 \\
\hline Cukup & 3 & 8,3 & 2 & 5,5 & 2 & 5,5 & 7 & 19,45 \\
\hline Kurang & 1 & 2,8 & 8 & 22,2 & 17 & 47,2 & 26 & 72,22 \\
\hline Jumlah & 5 & 14 & 11 & 30,5 & 20 & 55,5 & 36 & 100 \\
\hline
\end{tabular}

Menunjukkan terdapat hubungan ( $\left.r h o_{\text {hitung }}<\mathrm{Z}_{\text {tabel }}\right)$

Berdasarkan tabel 6 didapatkan Hasil uji Spearman Rank didapatkan $\rho$-value sebesar $0.017<\alpha(0.05)$ dan $r$ $=0,394$, artinya ada hubungan antara pengetahuan kanker leher ahim dengan motivasi wanita pasangan usia subur melakukan pemeriksaan IVA di RT 02 RW 02 Ds. Surat Kec. Mojo Kab. Kediri. 


\section{Diskusi}

Pengetahuan wanita pasangan usia subur tentang kanker leher Rahim di RT.02 RW.02 Ds. Surat Kec. Mojo Kab. Kediri

Kanker leher rahim adalah keganasan yang terjadi pada leher rahim yang merupakan bagian terendah dari rahim yang menonjol ke puncak liang senggama (Kemenkes RI,2013).

Masih tingginya kasus kanker leher rahim merupakan hal yang ironi. Hal ini karena kanker leher rahim merupakan penyakit yang telah diketahui penyebapnya dan diketahui perjalanan penyakitnya tetapi masih banyak wanita pasangan usia subur yang belum mengerti dan mengetahui tentang bahaya kanker leher rahim dan faktor penyebab kanker leher rahim.

Pengetahuan dan pemahaman seseorang terhadap objek juga dipengaruhi oleh informasi dan sumber informasi. Berdasarkan penelitian, didapatkan bahwa sebanyak 10 responden $(27,8 \%)$ mendapat informasi dari petugas kesehatan, 13 responden $(36,1 \%)$ mendapat informasi dari media massa, 4 responden $(11,1 \%)$ mendapat informasi dari media elektronik dan dari orang lain sebanyak 3 responden $(8,3 \%)$ sehingga sebagian besar wanita pasangan usia subur mendapat sumber informasi dari media massa.

Sebagaimana teori yang dikemukakan Budiman (2014) bahwa pendidikan adalah suatu usaha untuk mengembangkan kepribadian dan kemampuan di dalam dan di luar sekolah (baik formal maupun nonformal), berlansung seumur hidup.

Pendidikan yang rendah menunjukkan bahwa responden banyak yang tidak mengetahui tentang kanker leher rahim secara signifikan. Pendidikan zaman dahulu dan sekarang sudah sangat jauh berbeda, disamping itu perkembangan zaman yang semakin berkembang dan perubahan kurikulum yang semakin bertambah banyak juga dikarenakan zaman dahulu belum dikembangkan lebih meluas tentang pendidikan kesehatan, sehingga tingkat pendidikan sangat berpengaruh sekali dalam pengetahuan responden. Dengan tingkat pendidikan yang rendah maka pengetahuannya pun juga ikut rendah begitu juga sebaliknya. Tingkat pendidikan yang rendah mengakibatkan rasa ingin tahu responden kurang karena dengan pendidikan yang tinggi, akan tinggi pula pengetahuan, cara berpikir dan rasa ingin tahu yang tinggi dari responden tentang kanker leher rahim.

\section{Motivasi wanita pasangan usia subur melakukan pemeriksaan IVA di RT.02 RW.02 Ds. Surat Kec. Mojo Kab. Kediri \\ Pada kisaran umur 20-35 tahun} sebagian besar seseorang sudah mulai matang dalam berfikir dan bertindak sehingga wanita PUS akan lebih cepat menerima pengetahuan dan informasi yang diberikan termasuk pengetahuan tentang kanker leher rahim. Sehingga apabila wanita tersebut diberi informasi dan dianjurkan untuk melakukan pemeriksaan IVA, wanita PUS sudah bisa mengambil tindakan yang kooperatif untuk berfikir bahwa pemeriksaan IVA sangat penting untuk wanita PUS.

Faktor lain yang mempengaruhi motivasi wanita pasangan usia subur melakukan pemeriksaan IVA adalah pekerjaan responden. Berdasarkan tabel IV.2 hasil penelitian, mayoritas responden bekerja sebagai ibu rumah tangga yaitu sebanyak 31 orang $(86,2 \%)$. 


\section{Hubungan pengetahuan kanker leher Rahim dengan motivasi wanita pasangan usia subur melakukan pemeriksaan IVA di RT.02 RW.02 Ds. Surat Kec. Mojo Kab. Kediri}

Hasil uji Spearman Rank didapatkan $\rho$-value sebesar $0.017<\alpha(0.05)$ dan $\mathrm{r}=$ 0,394 , artinya ada hubungan antara pengetahuan kanker leher Rahim dengan motivasi wanita pasangan usia subur melakukan pemeriksaan IVA di RT 02 RW 02 Ds. Surat Kec. Mojo Kab. Kediri. Besarnya nilai $r=0,394$ menunjukkan hubungan yang sedang antara pengetahuan kanker leher Rahim dengan motivasi melakukan pemeriksaan IVA.

Penelitian menunjukan bahwa wanita pasangan usia subur yang memiliki pengetahuan yang tinggi akan termotivasi untuk melakukan pemeriksaan IVA. Sedangkan yang

\section{Daftar Pustaka}

Alimul, A, 2007. Metoe Penelitian dan Teknik Analisis Data. Yogyakarta: Salemba Medika. 2010. Metode Penelitian Kebidanan dan Teknik Analisis Data. Jakarta: Salemba Medika.

Arikunto, S, 2006. Prosedur Penelitian Suatu Pendekatan Praktik. Jakarta: Rineka Cipta.

Budiman, 2014. Kapita Selekta Kuesioner. Jakarta: Salemba Medika.

Cahyo, N, J, 2010. Awas!!! Bahaya Kanker Rahim dan Kanker Payudara. Yogyakarta: Wahana Totalita.

Emilia, O, 2010. Bebas Ancaman Kanker Servik.Yogyakarta:MedPress.

Faizah, S, 2010. Waspada Kanker Serviks. Yogyakarta: Lintang Aksara

Hamzah, B, 2011. Teori Motivasi dan Pengukurannya. Jakarta: Bumi Aksara.

Kementerian Kesehatan Indonesia, 2008. Petunjuk Teknis Standar Pelayanan Minimal Bidang Kesehatan, Jakarta: Kementerian Kesehatan RI [24 Februari 2017].

Notoatmodjo, S, 2010. Metodologi Penelitian Kesehatan. Jakarta: Rineka Cipta.

Nursalam, 2008. Pedoman Skripsi Tesis dan Instrumen Penelitian Keperawatan. Jakarta: Salemba Medika. memiliki pengetahuan kurang akan memiliki motivasi yang rendah. Motivasi sendiri dipengaruhi oleh dorongan untuk berbuat yang dilandasi oleh kebutuhannya yang dirasakannya. Dengan adanya kebutuhan melakukan pemeriksaan IVA akan menumbuhkan motivasi wanita pasangan usia subur karena mereka sadar bahwa hal tersebut merupakan suatu kebutuhan bagi dirinya sendiri yang harus dipenuhi.

\section{SIMPULAN}

Pengetahuan responden tetang kanker leher rahim 72,2 \% kurang dan motivasi responden untuk melakukan IVA 55,5\% rendah. Ada hubungan antara pengetahuan tentang kanker leher rahim dan motivasi melakukan IVA dengan Analisis Spearman Rank didapatkan $\rho$ value sebesar $0.017<\alpha(0.05)$ dan $\mathrm{r}=$ 0,394 .
2008. Konsep dan Penerapan Metodologi Penelitian Ilmu Keperawatan edisi XVI. Jakarta: Salemba Medika.

Priyanto, Samadi, 2010. Yes!I Know Everything about Kanker Serviks. Jakarta Timur: Tiga Kelana.

Setiadi, 2007. Konsep dan Penulisan Riset Keperawatan. Yogyakarta: Graha Ilmu.

Sujarweni, Wiratna, 2014. Metodologi Penelitian. Yogyakarta: Pustakabarupress.

Sugiyono, 2012. Satistika Untuk Penelitian. Bandung: Alfabeta.

2012. Metode Penelitian Kuantitatif Kualitatif dan R\&D. Bandung: Alfabeta. 2010. Statistika untuk Penelitian. Bandung. Alfabeta. 2008. Metode Penelitian Kuantitatif Kualitatif dan R\&D. Bandung: Alfabeta.

Taufik M, 2007. Prinsip-Prinsip Promosi Kesehatan Dalam Keperawatan Untuk Perawat Dan Mahasiswa Keperawatan. Jakarta: Rineka Cipta

Tilong, A, D, 2012. Bebas Dari Ancaman Kanker Serviks. Yogyakarta: FlashBooks.

Lestari, Tatik, 2015. Kumpulan Teori Untuk Kajian Pustaka Penelitian Kesehatan. Yogyakarta: Nuha Medika.

Wawan, A. \& M, Dewi, 2010. Teori \& Pengukuran Pengetahuan, Sikap dan Perilaku Manusia. Yogyakarta: Nuha Medika. 
Wijaya, Delia, 2010. Pembunuh Ganas Itu Bernama Kanker Serviks. Yogyakarta: Sinar Kejora.

Adelia, P, 2014. Faktor yang Berhubungan Dengan Tindakan Vaksinasi HPV Pada Wanita Dewasa [Online], hal.2. Diakses dari : http://www.slideshare.net/mobile/AdeliaPer wita/jurnal-adelia101011056fs01-59375293 [20 Maret 2017].

Anonim. 2007. Pertumbuhan Terapi dan Nanomedis [Online] Diakses dari: http://wwww.nano.lipi.go.id/utama.cgi?artik eldan1187593839 [ 25 Juli 2017].

Badan Pengembangan dan Pembinaan Bahasa, Kementerian Pendidikan dan Kebudayaan Republik Indonesia. 2017. KBBI Daring [Online] (Update 2016) Diakses dari: https://kbbi.kemdikbud.go.id/entri/kanker\% 20serviks [24 februari 2017].

Cancer Chemoprevention Research Center Fakultas farmasi UGM. 2014. Kanker Leher Rahim [Online] (Update 24 maret 2015) Diakses dari: http://ccrc.farmasi.ugm.ac.id/?page $\mathrm{id}=893$ [24 februari 2017].

Digital Library Universitas Muhammadiyah. 2014. Pengukuran Motivasi [Online] Diakses dari: http://digilip.unimus.ac.id/files/diks1/110/jtp tunimus-gdl-afipkhoiru-5471-4-babiii.pdf [17 April 2017].

Dinas Kesehatan Kabupaten Kediri. 2017.Profil Kesehatan Kabupaten Kediri [Online]. Diekses dari: http://dinkes.kedirikab.go.id/?hal=profilkese hatan [20 Maret 2017].

Hartati, Nyoman, 2014. Motivasi Wanita Usia Subur untuk Melakukan Pemeriksaan Inspeksi Visual Asam Asetat.[Online] Diakses dari: http://poltekes-

denpasar.ac.id/files/JURNAL\%20GEMA\% KEPERAWATAN/DESEMBER\%202014/ ARTIKEL $\% 20 \mathrm{Ni} \% 20$ Nyoman $\% 20$ hartati $\%$ dkk,.pdf [17 April 2017]. 